Azmi, et al/Jurnal Ekonomi Syariah Teori dan Terapan Vol. 6 No. 9 September 2019: 1851-1861; PENGUKURAN KINERJA REKSA DANA PADA REKSA DANA SYARIAH DAN REKSA DANA KONVENSIONAL DI INDONESIA PERIODE 2008 - 2018

\title{
PENGUKURAN KINERJA REKSA DANA PADA REKSA DANA SYARIAH DAN REKSA DANA KONVENSIONAL DI INDONESIA PERIODE $2008-2018$
}

\author{
Zulfiyah Azmi \\ Departemen Ekonomi Syariah-Fakultas Ekonomi dan Bisnis-Universitas Airlangga \\ Email: zulfiyahazmi@gmail.com \\ Bayu Arie Fianto \\ Departemen Ekonomi Syariah-Fakultas Ekonomi dan Bisnis-Universitas Airlangga \\ Email: bayu.fianto@feb.unair.ac.id
}

\begin{abstract}
:
This research measured and compared the performance between Islamic mutual funds and conventional mutual funds using Sharpe Ratio, Treynor Index, Jensen Alpha, Modigliani Measure, Appraisal Ratio, and Adjusted Sharpe Ratio. This research used quantitative approach with panel data that was measured by using different test and it aimed to find out the comparation of the samples. This research used Net Asset Value (NAV), Joint Stock Price Index, BI Rate to find out return and risk that will be implemented on the measured methods. The results of the research based on T-test are that there is no significant difference of performance between Islamic mutual funds and conventional mutual funds, except the Appraisal Ratio method that shows the difference on Islamic mutual funds that has a better performance.
\end{abstract}

Keywords: Sharpe Ratio, Treynor Index, Jensen Alpha, Modigliani Measure, Appraisal Ratio, Adjusted Sharpe Ratio..

\section{PENDAHULUAN}

Investasi merupakan suatu istilah dengan beberapa pengertian yang berhubungan dengan keuangan dan ekonomi. Istilah tersebut berkaitan dengan akumulasi suatu bentuk aktivitas dengan suatu harapan mendapatkan keuntungan pada masa depan. Investasi disebut juga sebagai penanaman modal seperti pendapat salah satu ahli ekonomi, investasi diartikan ialah sebagai pengeluaran atau pembelanjaan penanam-penanam suatu modal atau perusahaan untuk membeli barangbarang modal dan juga perlengkapan perlengkapan produksi untuk menambah kemampuan memproduksi barangbarang dan juga jasa-jasa yang tersedia dalam perekonomian (Sukirno, 2001: 107). Dalam melakukan kegiatan investasi, investor akan dihadapkan pada suatu ketidakpastian. Ketidakpastian atau risiko akan selalu dihadapi oleh para investor dalam berinvestasi karena dana tersebut digunakan dalam mengembangkan suatu perusahaan secara riil.

Di Indonesia sendiri sebagai negara berkembang juga mengalami pertumbuhan dalam tingkat perkembangan pasar modal. Masyarakat mulai menanamkan dananya untuk di investasikan pada perusahaan Reksa dana, maupun langsung ke pasar modal dimana lender dan borrower saling bertemu. Selama ini masyarakat pada umumnya masih belum mengetahui

\footnotetext{
${ }^{1}$ Jurnal ini merupakan bagian dari skripsi dari Zulfiyah Azmi, NIM : 041511433186 , yang diuji pada 23 Juli 2019.
} 
Azmi, et al/Jurnal Ekonomi Syariah Teori dan Terapan Vol. 6 No. 9 September 2019: 1851-1861; PENGUKURAN KINERJA REKSA DANA PADA REKSA DANA SYARIAH DAN REKSA DANA KONVENSIONAL DI INDONESIA PERIODE 2008 - 2018

tentang pasar modal. Tetapi dalam beberapa tahun terakhir perkembangan pasar modal Indonesia mengalami beberapa peningkatan kapitalisasi dimana dapat disimpulkan bahwa pasar modal Indonesia mulai bergeliat dan berkembang.

Islam berpandangan bahwa melakukan kegiatan investasi diperbolehkan, tetapi tujuannya tidak semata-mata untuk mendapatkan keuntungan pribadi saja. melainkan juga harus dapat menciptakan kesejahteraan atau kemaslahatan kepada semua umat. Praktek berinvestasi juga pernah dipraktekkan oleh Rasulullah SAW. Seperti yang kita ketahu bahwa Rasulullah SAW adalah seorang pedagang sejak kecil dan mempunyai ratusan unta untuk melamar istri pertamanya Siti Khadijah. Kekayaan seperti itu tidak hanya datang dari berdagang kain saja melainkan melakukan ekspansi bisnis ke bidang yang lain. Kesimpulanya bahwa sah-sah saja seseorang melakukan investasi. Bahkan Rasulullah sendiri melakukan hal tersebut. Ketika seseorang menyerahkan sebagian hartanya untuk berinvestasi maka dia juga tidak akan terlepas dari risiko atas dana yang diinvestasikanya.

Investasi terdapat sebuah teori yaitu high risk high return dimana jika seorang investor mengharapkan imbal balik yang tinggi maka dia akan mendapatkan risiko atau kegagalan yang besar juga. Risiko dalam investasi dibagi menjadi 2 (dua), yaitu risiko sistematis dan risiko tidak sistematis. Risiko sistematis disebut juga dengan risiko pasar (market risk) atau risiko yang tidak dapat dibagi (non-diversiable risk) merupakan risiko yang berasal dari kondisi ekonomi dan kondisi pasar secara umum tidak dapat didiversifikasikan yang dinyatakan dalam bentuk beta $(\beta)$.

Risiko tidak sistematis adalah bagian dari risiko yang dapat dihilangkan melalui diversifikasi. Risiko ini terkadang disebut juga risiko unik (unique risk). Risiko residual (residual risk) atau risiko khusus perusahaan. Nilai beta dari suatu perusahaan dipergunakan sebagai indikator untuk mengetahui risiko yang berkaitan dengan hubungan antara tingkat keuntungan suatu saham dalam pasar. Risiko ini berasal dari faktor fundamental perusahaan dan faktor karakteristik pasar terhadap saham perusahaan tersebut, dan selanjutnya menjadi variabel penentu tingkat pengembalian investasi.

Seorang investor perlu untuk selalu melakukan analisa pada risiko yang ada pada setiap saham-saham yang akan dimasukkan dalam portofolionya. Investor juga perlu untuk memperhitungkan faktor pengembalian investasi. Saham yang mempunyai return tinggi dan tidak likuid atau tidak mudah untuk dijual akan memberikan rasa kurang aman dalam return yang diharapkan oleh seorang investor meskipun saham tersebut menjanjikan return yang tinggi. Likuiditas yang rendah menyebabkan beban yang 
Azmi, et al/Jurnal Ekonomi Syariah Teori dan Terapan Vol. 6 No. 9 September 2019: 1851-1861; PENGUKURAN KINERJA REKSA DANA PADA REKSA DANA SYARIAH DAN REKSA DANA KONVENSIONAL DI INDONESIA PERIODE 2008 - 2018

ditanggung seorang investor juga tinggi. Investor akan kesulitan untuk menjual saham yang dia pegang apabila return saham sedang tinggi dari pembeliannya namun mempunyai likuiditas yang rendah.

Investasi pada instrumen saham dengan return yang relatif lebih besar daripada instrumen yang lain bukanlah hal yang mudah untuk dilakukan. Para nasabah akan dihadapkan pada beberapa kendala yaitu yang pertama jika berivestasi di instrumen saham harganya relatif mahal sehingga nasabah harus mempunyai dana yang cukup besar untuk dapat berinvestasi di instrumen saham, yang kedua nasabah harus mempunyai cukup ilmu pengetahuan dan pengalaman untuk dapat membaca pergerakan harga saham kapan waktu untuk menjual atau kapan waktu untuk membeli saham tersebut, dan yang ketiga adalah meskipun intrumen saham memberikan hasil yang lebih besar daripada instrumen yang lain invetasi saham juga mempunyai potensi risiko yang lebih besar pula dibanding dengan instrumen investasi yang lainnya.

Beberapa kendala tersebut membuat lembaga keuangan berpikir ulang untuk membuat produk yang memberikan hasil yang tinggi tetapi masih bisa dijangkau oleh semua kalangan nasabah. Sehingga munculah produk investasi yaitu reksa dana. Definisi reksa dana menurut Undang-undang Pasar Modal nomor 8 Tahun 1995 pasal 1, ayat (27): "Reksa dana adalah wadah yang dipergunakan untuk menghimpun dana dari masyarakat pemodal untuk selanjutnya diinvestasikan dalam portofolio efek oleh manajer investasi.". Kelebihan produk ini yaitu harganya yang relatif murah dan nasabah tidak harus mempunyai pengetahuan dan pengalaman yang cukup untuk dapat berinvestasi di instrumen ini. Selain itu dengan minimnya dana yang dikeluarkan oleh investor untuk memiliki investasi reksa dana memungkinkan investor untuk mendiversifikasikan dana yang diinvestasikan sehingga dapat meminimalisir risiko yang diterima seperti pernyataan ekonom yaitu, Diversifikasi investasi dalam berbagai instrumen efek dapat memperkecil risiko (Pratomo dan Nugraha, 2005: 12).

Perkembangan reksa dana di Indonesia begitu pesat bermula pada tahun 1976 yaitu pada saat PT. Danareksa didirikan oleh pemerintah. Reksa dana yang pertama kali diterbitkan bernama sertifikat Danareksa. Baru pada tahun 1995, dibuatlah UU No. 8 tahun 1995 mengenai pasar modal yang sebagian isinya mengatur tentang peraturan reksa dana. Di indonesia, reksa dana syariah pertama kali dibentuk dengan nama Danareksa syariah yang disahkan keberadaannya oleh Bapepam pada tanggal 12 Juni 1997. Reksa dana syariah yang didirikan itu berbentuk kontrak investasi kolektif (KIK) berdasarkan Udangundang No.8 tahun 1995 tentang pasar Modal, yang dituangkan dalam akta 
Azmi, et al/Jurnal Ekonomi Syariah Teori dan Terapan Vol. 6 No. 9 September 2019: 1851-1861; PENGUKURAN KINERJA REKSA DANA PADA REKSA DANA SYARIAH DAN REKSA DANA KONVENSIONAL DI INDONESIA PERIODE 2008 - 2018

Nomor 24 tanggal 12 Juni 1997 yang dibuat dihadapan Notaris Djedjem Wiajaya S.H. ji Jakarta antara PT. Danareksa Fund Management sebagai manajer investasi dengan Citibank N.A. sebagai bank kustodian.

Reksa dana terbagi menjadi empat jenis berdasarkan alokasi asetnya, seperti reksa dana pendapatan tetap, reksa dana pasar vang, reksa dana saham, dan reksa dana campuran. Setiap jenis reksa dana tersebut memiliki proporsi jumlah aset dan kinerja yang berbedabeda. Namun tak hanya itu, dalam perkembangannya reksa dana dibagi lagi menjadi dua berdasarkan basis operasionalnya yaitu reksa dana berbasis konvensional dan reksa dana berbasis syariah. Reksa dana syariah memberikan alternatif investasi yang lebih luas khususnya bagi para pemodal muslim. Perbedaan reksa dana syariah dengan konvensional adalah terletak pada pemilihan instrumen dan mekanisme investasi yang tidak boleh bertentangan dengan prinsip - prinsip syariah.

Pasca krisis ekonomi pada tahun 2009 banyak bank dengan sistem konvensional gulung tikar dikarenakan krisis yang tentu saja mempengaruhi keadaan keuangan negara. Hal ini membuktikan bahwa sistem ekonomi konvensional tidak tahan terhadap krisis. Namun, ditengah krisis yang terjadi perbankan yang menjalankan sistemnya dengan prinsip syariah tanpak tenang tenang saja. Perbankan syariah masih memenuhi kinerja yang relatif lebih baik dibandingkan perbankan konvensional selama krisis ekonomi tersebut. Hal ini dapat dilihat dari relatif rendahnya penyaluran pembiayaan yang bermasalah pada perbankan syariah dan terjadinya hambatan dalam kegiatan operasionalnya. Reksa dana yang juga merupakan instrumen keuangan tentu tidak terlepas dari pengaruh krisis keuangan ini. Namun, adanya reksa dana syariah ternyata membantu membangkitkan kembali perkembangan reksa dana yang sebelumnya terpuruk akibat terjadinya krisis keuangan tersebut.

Menurut Pratomo dan Nugroho (2014), kinerja reksa dana menjadi pertimbangan utama investor dalam memilih Reksa dana dan $70 \%$ investor memilih reksa dana berdasarkan kinerja yang dihasilkan. Sebagian investor lainnya, investor muslim juga membandingkan alternatif yang ada untuk dapat memperoleh tingkat pengembalian yang relatif tinggi dengan memperhatikan tingkat resiko yang di hadapi dalam mencapai tingkat pengembalian tersebut. Dengan demikian, hal ini akan membawa tuntutan kepada reksa dana syariah untuk meningkatkan kinerjanya. Tentu saja hal ini bukan hanya tuntutan investor muslim semata, tetapi juga investor lain secara umum yang ingin melihat reksa dana syariah dapat memiliki kinerja yang lebih baik dari reksa dana konvensional. 
Azmi, et al/Jurnal Ekonomi Syariah Teori dan Terapan Vol. 6 No. 9 September 2019: 1851-1861; PENGUKURAN KINERJA REKSA DANA PADA REKSA DANA SYARIAH DAN REKSA DANA KONVENSIONAL DI INDONESIA PERIODE 2008 - 2018

Lembaga keuangan menilai perkembangan produk syariah di Indonesia akan sangat diminati oleh penduduk Indonesia karena sebagian besar masyarakat Indonesia adalah seorang muslim, apalagi sebagai Negara yang mayoritas memeluk agama Islam telah diajarkan untuk menghindari instrumen investasi atau jual beli yang berbau riba, maysir, dan gharar. Banyak investor yang melihat nilai aktiva bersih (NAB) sebagai acuan dalam berinvestasi dan memperkirakan return yang diperoleh, karena semakin besar NAB maka return yang akan didapat juga semakin besar dan sebaliknya. Menurunnya NAB dapat disebabkan oleh harga pasar instrumen investasi mengalami penurunan dibanding harga pembelian awal.

Seorang investor Islam harus memperhitungkan risiko dan kinerja pengembalian dalam setiap kegiatan investasi. Islam menganjurkan agar dana yang dimiliki umatnya tidak menganggur dan harus diinvestasikan agar roda perekonomian terus berjalan dan memberikan kesejahteraan kepada sesamanya. Berkaca pada informasi diatas maka peneliti tertarik untuk meneliti bagaimana perbedaan kinerja reksa dana syariah dengan reksa dana konvensional dalam pengukuran risiko dan pengembalian investasinya dengan beberapa metode. Penelitian ini juga mengukur kinerja dari sebelum, selama, dan sesudah krisis yaitu pada tahun 20082018.

\section{LANDASAN TEORI DAN PENGEMBANGAN HIPOTESIS}

Penelitian ini menggunakan berbagai pengukuran kinerja yang disesuaikan dengan risiko untuk memperkirakan kinerja keseluruhan dana, dari sebelum, selama, dan sesudah krisis. Pertama, penelitian ini menggunakan rasio Sharpe (SR). SR adalah pengukuran yang disesuaikan dengan risiko dalam mengukur kinerja standar dana karena mengakui adanya pengembalian bebas risiko dalam portofolio aset. Dengan melibatkan aset bebas risiko dalam portofolio mereka, investor atau manajer dana dapat memilih portofolio berisiko, dan kemudian bergabung dengan aset bebas risiko untuk mencapai tingkat risiko absolut apapun (diukur dengan standar deviasi pengembalian portofolio), seperti yang mereka inginkan. DeFusco et al. (2007) menggambarkan investor yang menghindari risiko, mereka lebih suka portofolio dengan SR lebih besar daripada yang lebih kecil.

Karena tidak ada jaminan bahwa kinerja masa lalu adalah perkiraan terbaik untuk kinerja masa depan (Sharpe, 1966), ukuran SR harus diuji dengan metode lain. Treynor Index (TI) diterapkan karena alasan itu. Tl mengukur kelebihan pengembalian per unit risiko berdasarkan risiko sistematis (beta dari portofolio) daripada risiko total (standar deviasi) seperti yang digunakan dalam 
Azmi, et al/Jurnal Ekonomi Syariah Teori dan Terapan Vol. 6 No. 9 September 2019: 1851-1861; PENGUKURAN KINERJA REKSA DANA PADA REKSA DANA SYARIAH DAN REKSA DANA KONVENSIONAL DI INDONESIA PERIODE 2008 - 2018

menghitung SR. Beta dari sebuah portofolio, juga disebut sebagai risiko sistematis dari suatu portofolio. Pengukuran lain yang disesuaikan dengan risiko yang digunakan dalam penelitian ini adalah alpha Jensen. Ini mengukur pengembalian rata-rata pada portofolio di atas dan di atas yang diprediksi oleh CAPM, mengingat beta portofolio dan pengembalian pasar rata-rata (Bodie, Kane, \& Alan, 2010). Alfa Jensen adalah nilai alfa portofolio dalam regresi CAPM.

Studi ini kemudian menerapkan ukuran Modigliani (MM) yang diusulkan oleh Modigliani dan Modigliani (1997) sebagai alternatif untuk mengukur kinerja yang disesuaikan dengan risiko. Ini mengukur kinerja dana dalam kaitannya dengan pasar. Studi ini juga menerapkan rasio penilaian (AR) atau rasio informasi untuk mengukur kinerja dana. AR ini mengukur abnormal return per unit risiko yang pada prinsipnya dapat didiversifikasi dengan memegang portofolio indeks pasar (Bodie et al., 2010). Untuk membuat perbandingan lebih lanjut, penelitian ini juga mengadopsi adjusted sharpe ratio (ASR) untuk menghindari bias dalam estimasi standar deviasi. SR telah dimodifikasi oleh Jobson dan Korkie (1981) dengan menambahkan jumlah pengamatan (OBS) dalam model.

\section{METODE PENELITIAN}

Penelitian ini menggunakan pendekatan kuantitatif dengan data panel yang diuji beda bertujuan untuk mengetahui perbandingan pada sampel penelitian ini. Tujuan dari penelitian ini adalah untuk membandingkan kinerja reksa dana pada reksa dana syariah dengan reksa dana konvensional di Indonesia periode 2008-2018. Untuk menghitung kinerja reksa dana menggunakan 6 metode yaitu Sharpe Ratio, Treynor Index, Jensen Alpha, Modigliani Measure, Appraisal Ratio, dan Adjusted Sharpe Ratio. Selanjutnya dilakukan teknik analisis data yang digunakan dalam penelitian ini yaitu analisis statistik deskriptif, uji normalitas, dan uji beda dua sampel. Berikut devinisi varibel penelitian ini :

\section{Sharpe Ratio}

DeFusco (2007) menggambarkan investor menghindari risiko, mereka lebih memilih portofolio dengan Sharpe Ratio yang lebih besar daripada yang lebih kecil. Rumus dihitung sebagai persamaan berikut:

$$
S R=\frac{\bar{r}_{i}-\bar{r}_{f}}{\sigma_{i}}
$$

Dalam hal ini :

$\mathrm{SR}=$ Sharpe Ratio

$\bar{r}_{i}=$ Rata-rata pengembalian portofolio

$\bar{r}_{f}=$ Rata-rata pengembalian asset bebas risiko

$\sigma_{i}=$ Standar deviasi pengembalian portofolio

\section{Treynor Index}

Treynor Index mengukur kembali kelebihan per-unit risiko berdasarkan risiko sistematis (beta portofolio) daripada total risiko (standar deviasi) seperti yang digunakan dalam menghitung Sharpe Ratio. Beta portofolio, juga disebut 
Azmi, et al/Jurnal Ekonomi Syariah Teori dan Terapan Vol. 6 No. 9 September 2019: 1851-1861; PENGUKURAN KINERJA REKSA DANA PADA REKSA DANA SYARIAH DAN REKSA DANA KONVENSIONAL DI INDONESIA PERIODE 2008 - 2018

sebagai risiko sistematis portofolio, adalah standar deviasi portofolio dibagi dengan standar deviasi dari return dari pasar. Rumus dari Treynor Index adalah persamaan sebagai berikut:

$$
T I=\frac{\bar{r}_{i}-\bar{r}_{f}}{\beta_{i}}
$$

Dalam hal ini :

$\mathrm{TI}=$ Treynor Index

$\bar{r}_{i} \quad=$ Rata-rata pengembalian

portofolio

$\bar{r}_{f} \quad=$ Rata-rata pengembalian asset

bebas risiko

$\beta_{i} \quad=$ Beta portofolio

Pengukuran Beta portofolio

$$
\beta_{i}=\frac{\sigma_{i M}}{\sigma_{M}^{2}}
$$

$\sigma_{i} \quad=$ Standar deviasi pengembalian portofolio

\section{Jensen Alpha}

Jensen Alpha mengukur rata-rata pengembalian portofolio yang diprediksi oleh CAPM, mengingat beta portofolio dan pengembalian rata-rata pasar (Bodie, Kane, \& Alan, 2010). Jensen Alpha adalah nilai portofolio alpha dalam regresi CAPM. Hal ini dihitung pada persamaan sebagai berikut:

$$
\alpha_{i}=\bar{r}_{i}-\left[\bar{r}_{f}+\beta_{i}\left(\bar{r}_{M}-\bar{r}_{f}\right)\right.
$$

Dalam hal ini :

$\alpha_{i} \quad=$ Jensen Alpha

$\bar{r}_{i}=$ Rata-rata pengembalian

portofolio

$\bar{r}_{f} \quad=$ Rata-rata pengembalian asset bebas risiko

$\beta_{i} \quad=$ Beta portofolio $\bar{r}_{m} \quad=$ Pengembalian pasar

\section{Modigliani Measure}

Penelitian sejenis ini pernah diterapkan oleh Modigliani measure (MM) yang diusulkan oleh Modigliani dan Modigliani (1997) sebagai alternatif untuk mengukur kinerja risiko disesuaikan. Mengukur kinerja reksa dana dalam rangka pasar, persamaan sebagai berikut:

$$
M M=\frac{\bar{r}_{i}-\bar{r}_{f}}{\sigma_{i}} \times \sigma_{m}
$$

Dalam hal ini :

MM = Modigliani measure

$\bar{r}_{i}=$ Rata-rata pengembalian portofolio

$\bar{r}_{f} \quad=$ Rata-rata pengembalian asset bebas risiko

$\sigma_{i} \quad=$ Standar deviasi pengembalian portofolio

$\sigma_{m} \quad=$ Standar deviasi pengembalian pasar

\section{Appraisal Ratio}

Penelitian ini juga menerapkan Appraisal Ratio (AR) atau informasi rasio untuk mengukur kinerja Reksa dana. AR ini diperoleh ketika alpha portofolio dibagi dengan risiko non-sistematik portofolio (Bodie et al., 2010). Mengikuti perhitungannya adalah persamaan sebagai berikut:

$$
A R=\frac{\alpha_{i}}{\sigma\left(e_{i}\right)}
$$

Dalam hal ini :

$$
\begin{array}{ll}
\text { AR } & =\text { Appraisal ratio } \\
\alpha_{i} & =\text { Jensen Alpha } \\
\sigma\left(e_{i}\right) & =\text { Risiko non-sistematis portofolio }
\end{array}
$$

\section{Adjusted Sharpe Ratio}


Azmi, et al/Jurnal Ekonomi Syariah Teori dan Terapan Vol. 6 No. 9 September 2019: 1851-1861; PENGUKURAN KINERJA REKSA DANA PADA REKSA DANA SYARIAH DAN REKSA DANA KONVENSIONAL DI INDONESIA PERIODE 2008 - 2018

Untuk membuat perbandingan lebih lanjut, penelitian ini juga mengadopsi rasio Sharpe disesuaikan (ASR) untuk menghindari bias dalam estimasi standar deviasi. SR telah modifikasi oleh Jobson dan Korkie (1981) dengan menambahkan jumlah observasi (OBS) dalam model. Perhitungan tersebut dinyatakan pada persamaan sebagai berikut:

$$
A S R=\frac{S R \times O B S}{O B S+0.75}
$$

Dalam hal ini :

ASR = Adjusted sharpe ratio

$\mathrm{SR} \quad=$ Sharpe ratio

OBS = Jumlah observasi

\section{HASIL DAN PEMBAHASAN}

Berikut hasil uji normalitas yang diuji dari uji statistik definisi operasional :

Tabel 1

\begin{tabular}{|l|c|c|c|l|}
\hline $\begin{array}{c}\text { Varia } \\
\text { bel }\end{array}$ & $\begin{array}{c}\text { Reksa } \\
\text { dana }\end{array}$ & $\begin{array}{c}\text { Kolmog } \\
\text { orov- } \\
\text { Smirnov } \\
\mathbf{Z}\end{array}$ & $\mathbf{P}$ & $\begin{array}{c}\text { Ketera } \\
\text { ngan }\end{array}$ \\
\hline \multirow{2}{*}{$\begin{array}{l}\text { Sharp } \\
\mathbf{e} \\
\text { Ratio }\end{array}$} & $\begin{array}{c}\text { Konven } \\
\text { sional }\end{array}$ & 0,680 & $\begin{array}{c}0,7 \\
45\end{array}$ & Normal \\
\cline { 2 - 5 } & Syariah & 0,743 & $\begin{array}{c}0,6 \\
40\end{array}$ & Normal \\
\hline \multirow{2}{*}{$\begin{array}{l}\text { Treyno } \\
\mathbf{r} \\
\text { Index }\end{array}$} & $\begin{array}{c}\text { Konven } \\
\text { sional }\end{array}$ & 1,241 & $\begin{array}{c}0,0 \\
92\end{array}$ & Normal \\
\cline { 2 - 5 } & Syariah & 1,191 & 0,1 & Normal \\
\hline \multirow{2}{*}{$\begin{array}{l}\text { Jense } \\
\mathbf{n} \\
\text { Alpha }\end{array}$} & $\begin{array}{c}\text { Konven } \\
\text { sional }\end{array}$ & 2,705 & $\begin{array}{c}0,0 \\
51\end{array}$ & Normal \\
\cline { 2 - 5 } & Syariah & 2,675 & $\begin{array}{c}0,1 \\
02\end{array}$ & Normal \\
\hline
\end{tabular}

\begin{tabular}{|c|c|c|c|c|}
\hline \multirow{2}{*}{$\begin{array}{l}\text { Modig } \\
\text { liani } \\
\text { Meas } \\
\text { ure }\end{array}$} & $\begin{array}{c}\text { Konven } \\
\text { sional }\end{array}$ & 0,944 & $\begin{array}{l}0,3 \\
34\end{array}$ & Normal \\
\hline & Syariah & 1,650 & $\begin{array}{l}0,0 \\
90\end{array}$ & Normal \\
\hline \multirow{2}{*}{$\begin{array}{l}\text { Appra } \\
\text { isal } \\
\text { Ratio }\end{array}$} & $\begin{array}{c}\text { Konven } \\
\text { sional }\end{array}$ & 0,660 & $\begin{array}{l}0,7 \\
76\end{array}$ & Normal \\
\hline & Syariah & 0,891 & $\begin{array}{l}0,4 \\
05\end{array}$ & Normal \\
\hline \multirow{2}{*}{$\begin{array}{l}\text { Adjust } \\
\text { ed } \\
\text { Sharp } \\
\text { e } \\
\text { Ratio }\end{array}$} & $\begin{array}{c}\text { Konven } \\
\text { sional }\end{array}$ & 0,680 & $\begin{array}{l}0,7 \\
45\end{array}$ & Normal \\
\hline & Syariah & 0,867 & $\begin{array}{l}0,4 \\
39\end{array}$ & Normal \\
\hline
\end{tabular}

Sumber : data diolah

Berdasarkan hasil pengujian asumsi normalitas, dapat diketahui bahwa semua data penelitian memiliki nilai signifikansi $>0,05$. Maka analisis untuk menguji perbedaan kinerja reksa dana syariah dengan reksa dana konvensional dalam metode Sharpe Ratio, Treynor Index, Jensen Alpha, Modigliani Measure, Appraisal Ratio, dan Adjusted Sharpe Ratio dilakukan dengan menggunakan uji t independent. Lalu dilanjutkan dengan uji beda atau uji independent t-test karena uji normalitas memiliki nilai signifikansi normal. Berikut tabel hasil uji T :

Tabel 2

\begin{tabular}{|c|c|c|c|c|}
\hline Variabel & $\begin{array}{c}\text { Reksa } \\
\text { Dana }\end{array}$ & $\begin{array}{c}\text { Rata } \\
\text { rata }\end{array}$ & T & p \\
\hline \multirow{2}{*}{$\begin{array}{c}\text { Sharpe } \\
\text { Ratio }\end{array}$} & $\begin{array}{c}\text { Konvensio } \\
\text { nal }\end{array}$ & $\begin{array}{c}0,27 \\
5\end{array}$ & - & 0,85 \\
\cline { 2 - 4 } & Syariah & $\begin{array}{c}0,30 \\
7\end{array}$ & 8 & 9 \\
\hline Treynor & Konvensio & - & - & 0,16 \\
\hline
\end{tabular}


Azmi, et al/Jurnal Ekonomi Syariah Teori dan Terapan Vol. 6 No. 9 September 2019: 1851-1861; PENGUKURAN KINERJA REKSA DANA PADA REKSA DANA SYARIAH DAN REKSA DANA KONVENSIONAL DI INDONESIA PERIODE 2008 - 2018

\begin{tabular}{|c|c|c|c|c|}
\hline \multirow[t]{4}{*}{ Index } & nal & 0,02 & \multirow{4}{*}{$\begin{array}{c}1,41 \\
3\end{array}$} & \multirow[t]{4}{*}{2} \\
\hline & & 1 & & \\
\hline & \multirow{2}{*}{ Syariah } & 0,11 & & \\
\hline & & 7 & & \\
\hline \multirow{4}{*}{$\begin{array}{l}\text { Jensen } \\
\text { Alpha }\end{array}$} & Konvensio & 0,04 & \multirow{4}{*}{$\begin{array}{c}0,63 \\
1\end{array}$} & \multirow{4}{*}{$\begin{array}{c}0,52 \\
9\end{array}$} \\
\hline & nal & 7 & & \\
\hline & \multirow{2}{*}{ Syariah } & 0,02 & & \\
\hline & & 7 & & \\
\hline \multirow{3}{*}{$\begin{array}{c}\text { Modiglia } \\
\text { ni } \\
\text { Measure }\end{array}$} & Konvensio & 0,00 & \multirow{3}{*}{$\begin{array}{c}- \\
1,23 \\
5\end{array}$} & \multirow{3}{*}{$\begin{array}{c}0,22 \\
2\end{array}$} \\
\hline & nal & 8 & & \\
\hline & Syariah & $\begin{array}{c}0,04 \\
3\end{array}$ & & \\
\hline \multirow{4}{*}{$\begin{array}{l}\text { Apprais } \\
\text { al Ratio }\end{array}$} & Konvensio & 0,21 & \multirow{4}{*}{$\begin{array}{c}- \\
2,04 \\
3\end{array}$} & \multirow{4}{*}{$\begin{array}{c}0,04 \\
5\end{array}$} \\
\hline & nal & 0 & & \\
\hline & Svariah & 0,43 & & \\
\hline & & 8 & & \\
\hline \multirow{4}{*}{$\begin{array}{c}\text { Adjusted } \\
\text { Sharpe } \\
\text { Ratio }\end{array}$} & Konvensio & 0,36 & \multirow{4}{*}{$\begin{array}{c}- \\
0,14 \\
5\end{array}$} & \multirow{4}{*}{$\begin{array}{c}0,88 \\
5\end{array}$} \\
\hline & nal & 6 & & \\
\hline & Syariah & 0,40 & & \\
\hline & & 0 & & \\
\hline
\end{tabular}

Sumber: data diolah

Berdasarkan hasil analisis dapat

diketahui bahwa nilai signifikansi yang diperoleh untuk metode sharpe ratio sebesar 0,859 ( $p>0,05)$ sehingga hipotesis ditolak, maka dapat disimpulkan bahwa tidak ada perbedaan yang signifikan antara kinerja reksa dana syariah dengan reksa dana konvensional dalam metode Sharpe Ratio. Pada metode Treynor Index diketahui bahwa nilai signifikansi yang diperoleh sebesar $0,162(p>0,05)$ sehingga hipotesis ditolak, maka dapat disimpulkan bahwa tidak ada perbedaan yang signifikan antara kinerja reksa dana syariah dengan reksa dana konvensional dalam metode Treynor Index. Pada

metode Jensen Alpha diketahui bahwa nilai signifikansi yang diperoleh sebesar $0,529(p>0,05)$ sehingga hipotesis ditolak, maka dapat disimpulkan bahwa tidak ada perbedaan yang signifikan antara kinerja reksa dana syariah dengan reksa dana konvensional dalam metode Jensen Alpha.

Pada metode Modigliani Measure diketahui bahwa nilai signifikansi yang diperoleh sebesar 0,222 ( $p>0,05)$ sehingga hipotesis ditolak, maka dapat disimpulkan bahwa tidak ada perbedaan yang signifikan antara kinerja reksa dana syariah dengan reksa dana konvensional dalam metode Modigliani Measure. Pada metode Appraisal Ratio diketahui bahwa nilai signifikansi yang diperoleh sebesar $0,045(p<0,05)$ sehingga hipotesis diterima, maka dapat disimpulkan bahwa ada perbedaan yang signifikan antara kinerja reksa dana syariah dengan reksa dana konvensional dalam metode Appraisal Ratio. Pada metode Adjusted Sharpe Ratio diketahui bahwa nilai signifikansi yang diperoleh sebesar 0,885 $\quad(p>0,05)$ sehingga hipotesis ditolak, maka dapat disimpulkan bahwa tidak ada perbedaan yang signifikan antara kinerja reksa dana syariah dengan reksa dana konvensional dalam metode Adjusted Sharpe Ratio.

\section{SIMPULAN}

Berdasarkan hasil penelitian dan pembahasan yang telah dilakukan dengan metode Sharpe Ratio, Treynor Index, Jensen Alpha, Modigliani Measure, Appraisal Ratio, dan Adjusted Sharpe 
Azmi, et al/Jurnal Ekonomi Syariah Teori dan Terapan Vol. 6 No. 9 September 2019: 1851-1861; PENGUKURAN KINERJA REKSA DANA PADA REKSA DANA SYARIAH DAN REKSA DANA KONVENSIONAL DI INDONESIA PERIODE 2008 - 2018

Ratio dalam menganalisis kinerja reksa dana syariah dengan reksa dana konvensioal selama sebelum hingga sesudah masa krisis periode 2008-2018, maka simpulan yang dapat diambil adalah:

Bahwa kinerja reksa dana syariah dengan reksa dana konvensional tidak terdapat perbedaan kecuali pada metode Adjusted Sharpe Ratio, dimana lebih baik kinerja reksa dana syariah dibanding dengan reksa dana konvensional. Hal ini disebabkan dari nilai signifikan metode tersebut sebesar 0,045 $(p<0,05)$.

Hasil dari penelitian ini membuktikan bahwa kinerja reksa dana syariah lebih unggul dari kinerja reksa dana konvensional. Hal tersebut dikarenakan pada metode Sharpe Ratio, Treynor Index, Modigliani Measure, Appraisal Ratio, dan Adjusted Sharpe Ratio nilai kinerja reksa dana syariah selalu lebih diatas nilai reksa dana konvensional. Sedangkan kinerja pada Jensen Alpha, reksa dana konvensional lebih unggul dari kinerja reksa dana syariah, hal ini terlihat dari nilai rata-rata konvensional sebesar 0,047 dan syariah 0,027.

Dari semua penjelasan di atas, hal ini selaras dengan Firman Allah yang dijelaskan dalam ayat 34 dari Al-Qur'an surat Al-Lukman berikut:

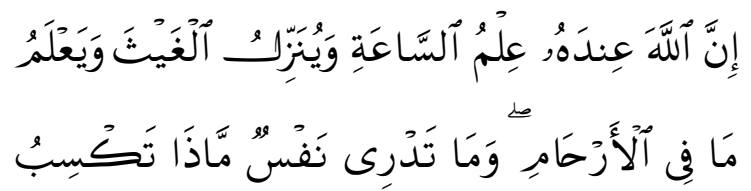

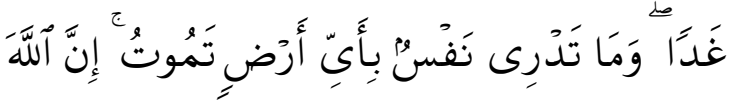

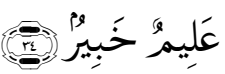

Inna'l-Lāha 'indahu 'ilmu's-sã'ati wayunazzilu'l-gaisa wa-ya'lamu mā fi 'arhāmi wa-mā tadri nafsun māżā taksibu gadan wa-mā tadri nafsun bi-'ayyi 'ardin tamütu inna'l-Lāha 'alimun khabir

Artinya: "Sesungguhnya Allah, hanya pada sisi-Nya sajalah pengetahuan tentang hari kiamat; dan Dialah Yang menurunkan hujan, dan mengetahui apa yang ada dalam rahim. Dan tiada seorangpun yang dapat mengetahui (dengan pasti) apa yang akan diusahakannya besok. Dan tiada seorangpun yang dapat mengetahui di bumi mana dia akan mati. Sesungguhnya Allah maha Mengetahui lagi Maha Mengenal. "(QS. Lukman: 34) (Kemenag $\mathrm{RI}, 2016)$

\section{DAFTAR PUSTAKA}

Abdul Halim. (2005). Analisis Investasi Edisi 2. Jakarta: Salemba Empat.

Adrian Sutedi. (2011). Pasar Modal Syariah Sarana Investasi Keuangan Berdasarkan Prinsip Syariah. Jakarta : Sinar Grafika.

Al-Bahar, J,.F. Crandall, K.C. (1990). Systematic Risk Management Approach for Construction Project. Journal of Construction Engineering Management. ASCE, 116 (3) 533-545.

Bodie, Zvi., Kane, Alex., Markus, Alan J., dan Jain, Ravi. (2010). Investments. Buku 1 dan 2. Terjemahan oleh, 
Azmi, et al/Jurnal Ekonomi Syariah Teori dan Terapan Vol. 6 No. 9 September 2019: 1851-1861; PENGUKURAN KINERJA REKSA DANA PADA REKSA DANA SYARIAH DAN REKSA DANA KONVENSIONAL DI INDONESIA PERIODE 2008 - 2018

Zulaini Dalimunthe dan Budi Wibowo. Jakarta: Salemba Empat.

COSO. (2004). Enterprise risk management- integrated framework. Committee of Sponsoring Organizations.

Devaney,M, Morillon, T \& Weber, W. 2016. Mutual fund efficiency andtradeoffs in the production ofrisk and return.Managerial Finance.Vol. 42. No: 3. pp. 225243.

Drobetz, Wolfgang and Kohler, Friederike. (2002). The Contribution of Asset Allocation Policy to Portfolio Performance. Working Paper. No. 2/02, Basel: WWZ/Departement of Finance University of Basel.

Eduardus Tandelilin. (2001). Analisis Investasi dan Manajemen Portofolio Edisi Pertama. Yogyakarta: BPFE-Yogyakarta.

Mansor, Fadillah, and $M$ Ishaq Bhatti. (2011). Risk and Return Analysis on Performance of the Islamic Mutual Funds: Evidence from Malaysia. Global Economy and Finance Journal, 4, 19-31.

Modigliani, F., \& Modigliani, L. (1997). Riskadjusted performance. Journal of Portfolio Management, 23(2), 4554.
Muhammad Firdaus. Et. Al. (2005). Investasi Halal di Reksa dana Syariah. Jakarta: Renaisa.

Shamsher, M., \& Annuar, M. N. (1995). The performance of unit trusts in Malaysia: Some evidence. Capital Market Review, 3, 51-64.

Sharpe, William F. (1966). Mutual Fund Performance. Journal of Business, V. 39, Part 2: pp 119-138.

Sudarsono, Heri. (2003). Bank dan Lembaga Keuangan Syariah. Yogyakarta: EKONISIA.

Sugiyono. (2015). Metode Penelitian Pendidikan (Pendekatan Kuantitatif, Kualitatif dan R\&D). Penerbit CV. Alfabeta: Bandung.

Sukirno, Sadono. (2011). Makro Ekonomi Teori Pengantar Edisi Ketiga. Rajawali Pers, Jakarta.

Sunariyah. (2011). Pengantar pengetahuan pasar modal. Edisi keenam. UPP STIM YKPN. Yogyakarta.

Suryani dan Hendryadi. (2015). Metode Riset Kuantitatif Teori dan Aplikasipada Penelitian Bidang Manajemen dan Ekonomi Islam. Jakarta: prenadamedia group. 